\title{
PENGARUH MODEL PEMBELAJARAN KOOPERATIF TIPE THINK PAIR SHARE (TPS) TERHADAP HASIL BELAJAR KEWIRAUSAHAAN SISWA KELAS X SMK NEGERI 3 SUNGAI PENUH
}

\author{
Oleh : Naskah \\ Universitas Islam Negeri Sultan Syarif Kasim Riau \\ E-mail : naskah20@gmail.com
}

\begin{abstract}
Abstrak
Penelitian ini bertujuan untuk mengungkapkan pengaruh dari model pembelajaran think pair share dengan model pembelajaran konvensional, pada mata pelajaran kewirasausahaan kelas $\mathrm{X}$ di SMKN 3 Sungai Penuh. Jenis penelitian ini yaitu quasi experiment dengan populasi siswa kelas X SMKN 3 Sungai Penuh. Jenis data berupa data primer dari hasil belajar siswa. Data dianalisis secara deskriptif dan induktif menggunakan "two ways of ANOVA". Dan hasil analisis tersebut dapat disimpulkan bahwa: (1) Hasil belajar siswa yang diajarkan dengan model pembelajaran kooperatif tipe Think Pair Share lebih tinggi daripada hasil belajar siswa yang diajarkan dengan model pembelajaran konvensional. (2) Tidak terdapat interaksi antara model pembelajaran kooperatif tipe Think Pair Share terhadap hasil belajar siswa.
\end{abstract}

Kata kunci : Model Pembelajaran Think Pair Share, dan interaksi

\section{Abstract}

This research was aimed at knowing the influence of learning model Cooperative type think pair at Enterpreneur lesson at the class X by SMKN 3 Sungai Penuh. The type of this research is a Quasi-experiment and the population of the reseach was the students of class X SMKN 3 Sungai Penuh. The sampling technique used was purposive sampling. Data were collected by using two different instruments. The type of data in the form of primary data from the results of student learning. While the data analysis was descriptive and inductive analysis by using two-ways of ANOVA. The results of the research are (1) Study results of students taught with cooperative learning model types Think Pair Share is higher than the results of the learning of students who are taught with the conventional learning model. (2) There is no interaction between the learning model cooperative types Think Pair Share against the learning outcomes of students.

Keywords : The Cooperetive learning type think pair share model, and interaction. 
PENDAHULUAN

Pendidikan diharapkan dapat menghasilkan manusia yang berkualitas, berakhlak dan bertanggung jawab serta mampu menyongsong kemajuan pada masa mendatang. Kualitas pendidikan pada setiap jenjang dan satuan pendidikan salah satunya dapat dilihat melalui hasil belajar yang diperoleh siswa. Berhasil atau tidaknya pencapaian tujuan pendidikan itu sangat tergantung pada banyak faktor baik yang berasal dari luar diri para siswa (faktor eksternal) maupun yang berasal dari dalam diri para siswa itu sendiri (faktor internal).

Faktor yang mempengaruhi hasil belajar, salah satunya adalah proses pembelajaran. Hasil belajar dapat dilihat dari terjadinya perubahan hasil masukan pribadi berupa motivasi dan rancangan pembelajaran yang dirancang oleh guru. Sesuai pendapat Sudjana (2009: 22) "Hasil belajar adalah kemampuan-kemampuan yang dimiliki siswa setelah menerima pengalaman belajarnya”. Hasil belajar yang diharapkan biasanya berupa prestasi belajar yang baik atau optimal. Namun dalam pencapaian hasil belajar yang baik masih saja mengalami kesulitan dan prestasi yang didapat belum dapat dicapai secara optimal.
Untuk memecahkan masalah pembelajaran yang demikian perlu dilakukan upaya yang antara lain pengembangan pembelajaran. Dalam pengembangan pembelajaran yang perlu dilakukan adalah pembelajaran yang inovatif dan kreatif.

Kenyataan yang dijumpai disekolah SMK Negeri 3 Sungai penuh menunjukkan bahwa dalam proses pembelajaran masih didominasi oleh guru sebagai pemberi pengetahuan bagi siswa (teacher center). Akibatnya kegiatan belajar mengajar kurang menarik dan membosankan karena siswa tidak diransang dan ditantang untuk terlibat aktif dalam pembelajaran.

Dalam pembelajaran, kebanyakan siswa hanya menunggu penjelasan dari guru dan belum di arahkan untuk belajar secara mandiri sehingga pemikiran siswa kurang berkembang. Hal ini cenderung membuat partisipasi belajar siswa rendah, perhatian dan minat siswa tidak dapat dipantau. Kebanyakan siswa malu untuk bertanya, mereka juga tidak berani menanggapi pertanyaan dan persoalan mengenai materi pelajaran serta tidak berani mengemukakan pendapatnya dalam proses pembelajaran. Jika tidak ada siswa yang bertanya maka guru cenderung menganggap bahwa siswa telah memahami 
materi pelajaran. Hal ini menyebabkan siswa yang sebenarnya masih kurang memahami materi pelajaran memperoleh hasil belajar yang kurang memuaskan sehingga siswa tidak memperoleh ketuntasan dalam belajar.

Berdasarkan hasil observasi awal penulis di SMK Negeri 3 Sungai penuh, ternyata rata-rata hasil belajar kewirausahaan siswa masih rendah, yang diukur dari hasil ujian tengah semester siswa kelas X SMK Negeri 3 Sungai Penuh Tahun Ajaran 2014/2015. Hal ini dapat dilihat pada tabel 1 berikut:

Tabel 1 Persentase Siswa yang Mencapai KKM pada Ujian Tengah Semester KLS X SMK N3 Sungai Penuh Tahun Pelajaran 2014/2015

\begin{tabular}{|c|c|c|c|c|c|c|c|}
\hline \multirow{3}{*}{$\begin{array}{l}\text { Kl } \\
\text { s }\end{array}$} & \multirow{3}{*}{$\begin{array}{l}\text { Jmlh } \\
\text { Siswa }\end{array}$} & \multirow{3}{*}{$\begin{array}{l}\text { Nilai } \\
\text { Rata- } \\
\text { Rata }\end{array}$} & \multirow{3}{*}{$\begin{array}{l}\mathbf{K} \\
\mathbf{K} \\
\mathbf{M}\end{array}$} & \multicolumn{2}{|c|}{$\begin{array}{l}\text { Siswa yang } \\
\text { Tuntas }\end{array}$} & \multicolumn{2}{|c|}{$\begin{array}{l}\text { Siswa yang } \\
\text { Tidak } \\
\text { Tuntas }\end{array}$} \\
\hline & & & & Jml & $\%$ & $\mathbf{J m l}$ & ( \\
\hline & & & & & ) & & ) \\
\hline \multirow{2}{*}{$\mathrm{X}_{1}$} & 22 & 60,95 & 70 & 9 & 40 & 13 & 59 \\
\hline & & & & & ,90 & & ,09 \\
\hline $\mathrm{X}_{2}$ & 20 & 61,96 & 70 & 4 & 20 & 16 & 80 \\
\hline \multirow{2}{*}{$X_{3}$} & 21 & 65,80 & 70 & 10 & 47 & 11 & 52 , \\
\hline & & & & & ,61 & & 38 \\
\hline \multirow{2}{*}{$X_{4}$} & 21 & 76,80 & 70 & 18 & 85 & 3 & 14 \\
\hline & & & & & ,71 & & ,28 \\
\hline \multirow{2}{*}{$\mathrm{X}_{5}$} & 19 & 66,82 & 70 & 10 & 52 & 9 & 47 \\
\hline & & & & & ,63 & & ,36 \\
\hline Jml & 103 & 66,66 & 70 & 51 & 49 & 52 & 50 \\
\hline $\mathrm{h}$ & & & & &, 51 & & , 48 \\
\hline
\end{tabular}

Sumber: Guru Kewirausahaan Kls X SMK Negeri 3 Sungai Penuh
Tabel di atas, memperlihatkan bahwa hasil belajar kewirausahaan siswa kelas X SMK Negeri 3 Sungai Penuh masih belum memuaskan. Secara keseluruhan ketuntasan belajar siswa belum mencapai $100 \%$ dan belum sesuai dengan apa yang diharapkan. Nilai semester yang diperoleh adalah siswa yang tuntas $49,51 \%$ dan yang belum tuntas $50,48 \%$, jumlah siswa yang tuntas 51 orang dari jumlah siswa seluruhnya 103 orang. Karena nilai rata-rata siswa masih banyak di bawah Kriteria Ketuntasan Minimum (KKM) yang ditetapkan oleh sekolah yaitu 70 , dengan nilai rata-rata tertinggi sebesar 76,80 yaitu kelas $\mathrm{X}_{4}$ dan nilai rata-rata terendah 60,95 kelas $X_{1}$. Kondisi ini membuktikan bahwa materi pelajaran kewirausahaan kurang dipahami siswa kelas $\mathrm{X}$ sehingga menyebabkan rendahnya hasil belajar kewirausahaan.

Berdasarkan pengamatan yang dilakukan penulis di SMK N 3 Sungai Penuh, berbagai pendekatan, model dan teknik pembelajaran telah dirancang untuk mengoptimalisasi mutu mata pelajaran kewirausahaan. Akan tetapi, usaha yang telah dilakukan oleh guru belum menampakkan hasil yang optimal. Dalam proses pembelajaran yang dilakukan guru, sebahagian besar siswa tidak tertantang 
untuk menemukan dan menguasai materi wirausaha.

Salah satu penyebab dari masih adanya nilai siswa yang kurang adalah masih kurangnya tingkat kreativitas siswa dan juga masih kurangnya tingkat keaktifan siswa dalam proses pembelajaran, selain itu guru masih lebih condong menggunakan metode pembelajaran ceramah, sehingga para siswa merasa bosan dalam mengikuti pembelajaran. Pembelajaran seperti ini berpusat pada guru yaitu dengan memadukan dengan metode ceramah, tanya jawab dan tanpa ada fariasi lain pada tiap kali mengajar. Siswa sebagai penerima dan pelaksanaan tugas dari guru yang merasa kurang termotivasi untuk aktif dalam pembelajaran kewirausahaan. Apabila guru memberikan kesempatan kepada siswa untuk bertanya tentang materi yang belum dipahami mereka hanya diam dan tidak mau bertanya.

Pada saat pembelajaran berlangsung sebahagian besar dari siswa cenderung pasif mereka malas untuk bertanya, tidak mau mengeluarkan pendapat ketika ditanya guru diam saja, sehingga kemampuan berfikir kritis siswa tidak terlatih. Partisipasi siswa dalam proses pembelajaran masih rendah, keadaan ini sebahagian siswa terlihat aktivitas negatifnya, seperti mengganggu teman saat guru menjelaskan, mengobrol, main handphone dan lain sebagainya. Maka dibutuhkan pengembangan metode pembelajaran guna menciptakan lingkungan pembelajaran yang dapat meningkatkan peran aktif siswa dan meningkatkan hasil belajar kewirausahaan.

Untuk memahami materi pembelajaran diharapkan guru dapat memilih model model pembelajaran untuk membantu peserta didik dalam memahami materi tersebut. Selain itu, alur proses belajar mengajar tidak harus berasal dari guru menuju peserta didik. Peserta didik bisa juga saling mengajar dengan sesama peserta didik lainnya (peer teaching). Ini merupakan sistem pengajaran yang memberikan kesempatan untuk bekerja sama dengan sesama peserta didik dalam tugas-tugas yang terstruktur atau bisa disebut cooperative learning. Ironisnya, model pembelajaran kooperatif ini belum banyak diterapkan dalam kegiatan belajar mengajar, karena banyak guru yang enggan menerapkan sistem kerjasama di dalam kelas karena beberapa alasan. Alasan yang paling utama adalah kekhawatiran bahwa akan terjadi kekacauan di kelas dan peserta 
didik tidak fokus terhadap pelajaran selama proses pembelajaran berlangsung.

Untuk meningkatkan hasil belajar kewirausahaan maka perlu melakukan pembaharuan pradigma menelaah proses belajar siswa, interaksi antara siswa dengan guru. Sistem pembelajaran selayaknya memberikan kesempatan bagi anak didik untuk bekerjasama dengan sesama siswa dalam tugas terstruktur dimana siswa belajar, bekerja dan berinteraksi di dalam kelompok-kelompok kecil. Sehingga siswa dapat bekerja sama saling membantu dan berdiskusi dalam memahami suatu mata pelajaran atau mengerjakan tugas kelompok. Salah satu model pembelajaran yang memungkinkan siswa untuk berinteraksi satu sama lain adalah model pembelajaran kooperatif.

\section{Model Pembelajaran Kooperatif} memiliki beberapa tipe. Salah satu tipe model pembelajaran kooperatif yang dapat membangun kepercayaan diri siswa dan mendorong partisipasi mereka dalam kelas adalah Model Pembelajaran Kooperatif tipe Think-Pair-Share. Model Pembelajaran tipe Think Pair Share (TPS) yang dapat memberikan siswa lebih banyak waktu berpikir, untuk merespons dan saling membantu (Trianto,2009:81). Model Pembelajaran Kooperatif Tipe Think Pair
Share (TPS) ini merupakan salah satu model pembelajaran yang terdiri dari 3 tahapan yaitu thinking (berfikir), pairing (berpasangan), dan sharing (berbagi) yang digunakan untuk mempengaruhi pola interaksi siswa. Sementara itu, L. Surayya (2014:3) "Model pembelajaran think-pairshare sangat ideal untuk guru dan siswa yang baru belajar kolaboratif.

Teknik pembelajaran think pair share memberi siswa kesempatan untuk bekerja sendiri serta bekerja sama dengan orang lain.. Hal ini menunjukkan bahwa penggunaan Model Pembelajaran Kooperatif tipe Think-Pair-Share sebagai salah satu upaya dalam meningkatkan hasil belajar siswa. Model Pembelajaran kooperatif tipe Think-Pair-Share cocok digunakan di SMK karena kondisi siswa SMK yang masih dalam masa remaja membuat mereka menyukai hal baru dan lebih terbuka dengan teman sebaya dalam memecahkan permasalahan yang mereka hadapi.

Kelebihan dari model kooperatif tipe Think Pair Share menurut Lie (2002:46) mengemukakan bahwa kelebihan Think Pair Share adalah siswa lebih cenderung aktif berdiskusi berdua teman sebangku sehingga tidak terjadi lagi ada siswa yang tidak bekerja dalam 
kelompok jika dalam kelompok terdiri dari 2 sampai 4 orang dan juga interaksi antar siswa lebih mudah sehingga banyak kesempatan untuk memberikan kontribusi dalam kelompok. Biasanya, guru mengajukan pertanyaan kepada seluruh siswa dan siswa memberikan jawaban setelah mengangkat tangan dan ditunjuk oleh guru, dengan model kooperatif tipe Think Pair Share ini siswa diberi kesempatan untuk berpikir sendiri, berdiskusi, saling membantu dalam kelompoknya untuk menjawab pertanyaan dari guru dan diberi kesempatan untuk berbagi dengan siswa lain.

Berdasarkan uraian di atas model pembelajaran kooperatif tipe Think Pair Share (TPS) dapat melatih kemampuan berpikir siswa, membuat siswa bertanggung jawab, bekerja sama, mengeluarkan pendapat, memahami materi baik secara individu maupun melalui bantuan orang lain dan juga mampu mengaktifkan siswa pada saat pembelajaran berlangsung.

Menyadari pentingnya penerapan model pembelajaran yang dilakukan untuk meningkatkan hasil belajar, maka penulis tertarik melakukan penelitian yang berjudul: "Pengaruh Model Pembelajaran Kooperatif Tipe Think
Pair Share Terhadap Hasil Belajar Kewirausahaan Siswa Kelas X SMK N 3 Sungai Penuh".

\section{METODE PENELITIAN}

Penelitian ini termasuk jenis penelitian Quasy eksperimen yaitu eksperimen yang memiliki perlakuan (treatments), pengukuran-pengukuran dampak (outcome measures), dan unit-unit eksperiment (experimental units) namun tidak menggunakan penempatan secara acak. Populasi dalam penelitian ini adalah siswa kelas X SMK Negei 3 Sungai Penuh dengan jumlah siswa 103 orang. Sampel dalam penelitian ini adalah kelas $\mathrm{X}_{1}$ sebagai kelas eksperimen yaitu kelas yang diberikan perlakuan berupa penggunaan model pembelajaran Think Pair Share dan kelas $\mathrm{X}_{2}$ SMK Negeri 3 Sungai Penuh sebagai kelas kontrol yaitu kelas yang menggunakan model pembelajaran konvensional. Sampel penelitian ini berjumlah 42 orang siswa terdiri dari 22 orang siswa kelas eksperimen dan 20 orang siswa kelas kontrol.

Teknik pengumpulan datanya menggunakan dua tahap yaitu: (1) Tahap persiapan, yaitu penyusunan instrumen, uji coba instrumen dan verifikasi instrumen. Instrumen yang digunakan adalah 
instrumen tes untuk hasil belajar. Kegiatan penyusunan instrumen penelitian bertujuan untuk menyusun dan mengembangkan kisikisi dan butir-butir yang akan dijadikan isi dari instrumen penelitian, setelah kegiatan penyusunan dan pengembangan instrumen kemudian dilanjutkan dengan uji coba instrumen. Uji coba instrumen ini dilakukan terhadap 30 orang siswa diluar kelas penelitian. Tujuan uji coba ini adalah untuk menganalisis butir-butir yang ada di dalam instrumen dan sekaligus memverifikasi instrumen tersebut, terutama yang berkaitan dengan daya beda dan tingkat kesukaran untuk tes hasil belajar. Usaha yang dilakukan dalam mengembangkan instrumen ini agar memiliki validitas yang baik adalah: 1) tahap mengembangkan butir-butir instrumen sesuai dengan indikator yang berkaitan dengan materi pokok; 2) melakukan uji coba instrumen kepada siswa diluar kelas sampel, dan 3) melakukan analisis data uji coba. Instrumen tes hasil belajar setelah dilakukan uji coba diukur validitas, realibiltas, daya beda dan tingkat kesukaran. 4) Tahap pelaksanaan yaitu berupa penjaringan data melalui instrumen penelitian terhadap responden siswa yang menjadi sampel penelitian.

\section{HASIL DAN PEMBAHASAN HASIL PENELITIAN}

Untuk menganalisis penelitian, maka data diolah dengan teknik analisis data yaitu analisis deskriptif dan analisis induktif. Deskriptif data bertujuan untuk menggambarkan data yang dikumpulkan dari responden. Analisis induktif digunakan untuk uji prasyarat dan hipotesis.

Pada pelaksanaan penelitian, penulis menetapkan Kompetensi Dasar yang diajarkan pada kelas sampel. Kompetensi Dasar yang penulis pilih adalah resiko usaha dan pengambilan keputusan. Pada kedua kelas sampel digunakan dua model pembelajaran yang berbeda. Pada kelas eksperimen digunakan model pembelajaran Think Pair Share sedangkan pada kelas kontrol digunakan model pembelajaran konvensional. Hal ini bertujuan untuk melihat hasil belajar siswa kedua kelas sampel. Pembelajaran dilaksanakan selama 4 kali pertemuan untuk masing-masing kelas sampel.

Data hasil belajar diambil dari hasil tes yang dilakukan setelah menerapkan model pembelajaran dimasing-masing kelas sampel. Pada kelas eksperimen digunakan model pembelajaran Think Pair Share sedangkan pada kelas kontrol 
digunakan model pembelajaran konvensional. Tes hasil belajar dilaksanakan setelah pembelajaran selesai. Dari sampel hasil belajar dapat disusun kelas interval, frekuensi, serta nilai dari mean, median, modus, standar deviation, variasi, skor minimum dan skor maksimum - Hasil belajar kelas eksperimen berisi tentang hasil belajar dari 22 orang siswa kelas $\mathrm{X}_{1}$ SMK N 3 Sungai Penuh. Selanjutnya pengolahan dilakukan dengan bantuan program SPSS 16.0 didapat distribusi hasil belajar pada tabel 2 berikut:

Tabel 2

Distribusi Frekuensi Hasil Belajar

Kewirausahaan Kelas Eksperimen

\begin{tabular}{ccccc}
\hline & & \multicolumn{3}{c}{ Kelas } \\
No & Interval & \multicolumn{2}{c}{ Eksperimen } & Keterangan \\
& & Fi & $\%$ & \\
\hline 1 & $89-94$ & 3 & 13,64 & Tuntas \\
2 & $83-88$ & 6 & 27,27 & Tuntas \\
3 & $78-82$ & 4 & 18,18 & Tuntas \\
4 & $72-77$ & 6 & 27,27 & Tuntas \\
5 & $67-71$ & 2 & 9,09 & Tuntas \\
6 & $61-66$ & 1 & 4,55 & Tidak Tuntas \\
& Jumlah & $\mathbf{2 2}$ & $\mathbf{1 0 0}$ & \\
& Mean & $\mathbf{7 9 , 8 1}$ & & \\
& Median & $\mathbf{8 0}$ & & \\
& Modus & $\mathbf{8 6}$ & & \\
Standar Deviasi & $\mathbf{7 , 8 2}$ & & \\
Variansi & $\mathbf{6 1 , 2 0}$ & & \\
Minimum & $\mathbf{9 3}$ & & \\
Maksimum & $\mathbf{6 3}$ & & \\
\hline
\end{tabular}

Sumber : Pengolahan Data Primer 2015.
Berdasarkan Tabel 2 di atas menggambarkan bahwa jumlah siswa yang tuntas pada kelas eksperimen sebanyak 21 orang sementara yang tidak tuntas sebanyak 1 orang. Nilai mean (nilai ratarata) kelas eksperimen adalah 79,81 menunjukkan bahwa kelas eksperimen berada diatas Nilai Kriteria Kelulusan Minimum (KKM) besarnya yaitu 70. Nilai tertinggi (maksimum) dan nilai terendah (minimum) kelas eksperimen adalah 93 dan nilai maksimum adalah 63. Sementara standar deviasi (penyebaran perolehan skor terhadap nilai rata-ratanya) kelas eksperimen adalah sebesar 7,82.

Sementara untuk melihat hasil belajar siswa pada kelas kontrol didapat distribusi hasil belajar pada tabel 3 berikut: 
Tabel 3

Distribusi Frekuensi Prestasi belajar

Kewirausahaan Kelas Kontrol

\begin{tabular}{ccccc}
\hline \multirow{2}{*}{ No } & \multirow{2}{*}{ Interval } & \multicolumn{2}{c}{ Kelas Kontrol } & \multirow{2}{*}{ Keterangan } \\
& & Fi & $\mathbf{\%}$ & \\
\hline 1 & $76-81$ & 5 & 25 & Tuntas \\
2 & $71-75$ & 4 & 20 & Tuntas \\
3 & $66-70$ & 4 & 20 & Tuntas \\
4 & $61-65$ & 1 & 5 & Tidak Tuntas \\
5 & $56-60$ & 3 & 15 & Tidak Tuntas \\
6 & $50-55$ & 3 & 15 & Tidak Tuntas \\
Jumlah & $\mathbf{2 0}$ & $\mathbf{1 0 0}$ & \\
Mean & $\mathbf{6 7 , 2}$ & & \\
Median & $\mathbf{7 0}$ & & \\
Modus & $\mathbf{7 3}$ & & \\
Standar Deviasi & $\mathbf{7 , 2 4}$ & & \\
Variansi & $\mathbf{8 9 , 9}$ & & \\
Minimum & $\mathbf{8 0}$ & & \\
Maksimum & $\mathbf{5 0}$ & & \\
\hline Sumber: Pengolahan Data Primer 2015 &
\end{tabular}

Berdasarkan Tabel 3 di atas menggambarkan bahwa jumlah siswa yang tuntas pada kelas kontrol hanya sebanyak 11 orang sementara yang tidak tuntas sebanyak 9 orang. Nilai mean (nilai ratarata) kelas kontrol adalah 67,2 menunjukkan bahwa kelas kontrol berada di bawah Nilai Kriteria Kelulusan Minimum (KKM) besarnya yaitu 70. Nilai tertinggi (maksimum) dan nilai terendah (minimum) kelas kontrol adalah 80 dan nilai maksimum adalah 50. Sementara standar deviasi (penyebaran perolehan skor terhadap nilai rata-ratanya) kelas kontrol adalah sebesar 7,24.

Dari penjelasan dan data ketuntasan kedua tabel distribusi frekuensi hasil belajar kelas eksperimen dan kelas kontrol tersebut dapat disimpulkan bahwa berdasarkan nilai kriteria ketuntasan minimal sebesar 70, terdapat 21 orang siswa pada kelas eksperimen yang mencapai nilai sama atau lebih dari nilai KKM, sedangkan pada kelas kontrol hanya terdapat 11 orang siswa yang nilainya mencapai nilai sama atau lebih dari nilai KKM nya. Data tersebut menerangkan bahwa kelas eksperimen dengan penerapan model pembelajaran Think Pair Share lebih baik daripada kelas kontrol yang menerapkan model Konvensional.

Setelah dilakukan uji normalitas dan homogenitas dimana data yang diolah berdistribusi normal dan homogeny maka langkah selanjutnya penulis meneruskan pada analisis varians dua jalur. Dalam pengujian hipotesis pada analisis varians dua jalur, kriteria untuk menolak atau menerima Ho berdasarkan pada Significance (yang disingkat Sig.).Jika Nilai Sign. $\leq \alpha$ maka Ho ditolak, jika Sign. $>\alpha$ maka Ho diterima. Berikut data hasil perhitungan ANOVA dua arah: 
Tabel 5 Estimasi Anova Dua Arah

\begin{tabular}{|c|c|c|c|c|c|}
\hline $\begin{array}{l}\text { Dependent } \\
\text { Variable:Ha }\end{array}$ & belajar & & & & \\
\hline & Type III Sum & & & & \\
\hline Source & of Squares & $\mathrm{df}$ & Mean Square & F & Sig. \\
\hline $\begin{array}{l}\text { Corrected } \\
\text { Model }\end{array}$ & $1806.331^{\mathrm{a}}$ & 3 & 602.110 & 8.011 & .000 \\
\hline Intercept & 224086.976 & 1 & 224086.976 & $2.981 \mathrm{E} 3$ & .000 \\
\hline Model & 1752.668 & 1 & 1752.668 & 23.319 & .000 \\
\hline Error & 2856.145 & 38 & 75.162 & & \\
\hline Total & 233472.000 & 42 & & & \\
\hline $\begin{array}{l}\text { Corrected } \\
\text { Total }\end{array}$ & 4662.476 & 41 & & & \\
\hline
\end{tabular}

R Squared $=.387$ (Adjusted R Squared $=.339$ )

Sumber : Pengolahan Data Primer

Berdasarkan hasil perhitungan

ANOVA dua arah didapat nilai R Squeared sebesar 0,387 dapat diartikan bahwa variabel model pembelajaran menjelaskan hasil belajar sebesar $38,7 \%$. Berdasarkan hasil pengujian dihasilkan: (1) Terlihat hasil belajar kelas eksperimen lebih tinggi daripada kelas kontrol, dan (3) tidak terdapat interaksi antara model pembelajaran.

\section{PEMBAHASAN}

Dengan memperhatikan dan mencermati paparan hasil penelitian pada bagian sebelumnya, dapat penulis kemukakan pembahasan dari penelitian sebagai berikut :

\section{Model pembelajaran Kooperetif} Tipe Think Pair Share Secara Signifikan memiliki Hasil Belajar Siswa lebih tinggi dari pada Model Pembelajaran Konvensional di Kelas X SMKN 3 Sungai Penuh

Berdasarkan hasil pengujian hipotesis mengungkapkan bahwa hasil belajar siswa yang dibelajarkan dengan model pembelajaran kooperatif tipe Think Pair Share secara signifikan lebih tinggi dari hasil belajar siswa yang dibelajarkan dengan model pembelajaran konvensional. Hal ini berarti hasil belajar siswa pada kelas eksperimen lebih baik dari pada hasil belajar siswa pada kelas kontrol. Siswa pada kelas eksperimen memperoleh ratarata hasil belajar 79,81 sedangkan siswa pada kelas kontrol memperoleh rata-rata hasil belajar 67,2.

$$
\text { Berhasilnya }
$$

model

pembelajaran Think Pair Share dalam meningkatkan hasil belajar siswa karena model pembelajaran Think Pair Share merupakan kegiatan pembelajaran dimana siswa dikelompokkan dalam kelompokkelompok kecil secara heterogen. 
Aktivitas siswa selama proses pembelajaran menggunakan Model Pembelajaran Kooperatif Tipe Think Pair Share (berfikir, berpasangan dan berbagi) dengan melewati tiga tahap. Tahap pertama yaitu tahap berfikir secara individu menyelesaikan tugas yang diberikan. Hal ini mengidentifikasi bahwa siswa pada kelas eksperimen lebih bersemangat dalam pembelajaran. Dalam mengerjakan soal tingkat partisipasi siswa pada kelas eksperimen lebih tinggi dari pada kelas kontrol.

$$
\text { Model pembelajaran }
$$

kooperatif tipe Think Pair Share lebih efektif untuk meningkatkan hasil belajar dalam pembelajaran kewirausahaan terutama materi mengambil resiko usaha dan membuat keputusan karena model kooperatif terbukti sebagai proses pembelajaran yang aktif, sebab peserta didik akan lebih banyak belajar melalui proses pembentukan dan penciptaan, kerja dalam kelompok dan berbagi pengetahuan. Kegiatan belajar peserta didik secara berkelompok lebih sukses secara akademis dibandingkan bekerja sendiri karena kerja kelompok mendorong peserta didik untuk saling membantu satu sama lain untuk mencapai hasil yang diharapkan. Model pembelajaran kooperatif tipe Think Pair Share unggul dalam membantu siswa memahami konsepkonsep sulit. Para pengembang model ini telah menunjukkan bahwa model struktur penghargaan kooperatif telah dapat meningkatkan nilai siswa pada belajar akademik dan perubahan norma yang berhubungan dengan hasil belajar.

Berdasarkan analisis deskriptif, secara umum dapat diketahui bahwa Hasil Belajar Siswa kelas eksperimen yang diterapkan Model Pembelajaran Kooperatif Tipe Think Pair Share lebih tinggi dibandingkan dengan kelas kontrol yang diterapkan metode pembelajaran konvensional. Hal ini bisa dilihat dari perbandingan rata-rata kedua kelas pada saat dilakukan posttest. Pada saat posttest, rata-rata kelas eksperimen lebih tinggi dibandingkan dengan kelas kontrol. Hal ini berarti kelas yang diberikan perlakuan dengan menggunakan Model Kooperatif Tipe Pembelajaran Think Pair Share lebih baik hasil belajarnya 
dibandingkan dengan kelas yang diberi perlakuan dengan metode konvensional.

Oleh sebab itu, Model Pembelajaran Kooperatif Tipe Think Pair Share dapat menjadi strategi guru untuk dapat meningkatkan Hasil Belajar Siswa. Temuan ini sejalan dengan pendapat Trianto (2012:81) pembelajaran Think Pair Share (TPS) dapat memberikan siswa lebih banyak waktu berpikir, untuk merespons dan saling membantu merupakan teknik yang mudah dilakukan dan dapat dipakai untuk mengetahui kebutuhan dan harapan siswa, sehingga pembelajaran akan bermakna.

Sedangkan menurut Febrian (2012:;45) untuk meningkatkan aktivitas belajar siswa, pembelajaran harus dialihkan yang semula berpusat pada guru menjadi pembelajaran yang berpusat pada siswa. Hal ini dapat dilakukan dengan cara menerapkan model pembelajaran yang dapat meningkatkan aktivitas belajar dan hasil belajar siswa seperti menerapkan model pembelajaran kooperatif tipe Think Pair Share.
Hasil penelitian yang dilakukan oleh Surayya (2014) menyimpulakan bahwa hasil belajar dapat ditingkatkan dengan penerapan model pembelajaran TPS, implikasi berdasarkan temuan hasil penelitian ini adalah penggunaan model pembelajaran think pair share dapat dipertimbangkan untuk diimplementasikan dalam proses pembelajaran TPS yang akan meningkatkan hasil belajar baik pada siswa yang memiliki keterampilan berpikir kritis maupun rendah, hasil belajar justru meningkat signifikan pada model pembelajaran yang diterapkan.

Sementara itu di kelas kontrol hasil belajar siswa lebih rendah. Dimana dalam kelas kontrol menerapkan model pembelajaran konvensional yang didalamnya terdapat kegiatan pembelajaran berupa presentasi/ceramah, diskusi, demonstrasi, tanya jawab, latihan dan tugas. Guru memberikan materi dan bahan ajar kepada siswa, siswa membaca materi, guru menerangkan materi, memberikan pertanyaan, memberi latihan, membahas latihan bersama siswa dan menerangkan 
kembali materi yang tidak dipahami siswa. Dengan pembelajaran yang berlangsung searah membuat siswa menjadi bosan dan kurang bersemangat mengikuti pembelajaran, sehingga pada penelitian ini hasil belajar siswa kelas kontrol lebih rendah dibanding kelas eksperimen.

Berdasarkan pendapat yang telah dikemukakan di atas, dan dihubungkan dengan penelitian ini, dapat diambil kesimpulan siswa yang diajarkan dengan model pembelajaran tipe Think Pair Share memiliki hasil belajar lebih baik dibandingkan siswa yang diajarkan

\section{Interaksi antara penggunaan model} pembelajaran terhadap hasil belajar

Berdasarkan hasil pengujian hipotesis diperoleh nilai sig. 0,214 lebih besar dari nilai $\alpha=0,05$, jadi dapat disimpulkan terdapat interaksi antara model pembelajaran dalam mempengaruhi hasil belajar siswa (Ho diterima). Hal ini sejalan dengan yang diungkapkan Irianto (2010:255) jika Ho diterima maka berarti efek faktor A tidak tergantung pada faktor B dan efek faktor B juga tidak tergantung pada faktor $\mathrm{A}$, ini berarti masingmasing faktor (model pembelajaran) saling tergantung atau independen antara satu dengan yang lainnya dalam mempengaruhi hasil belajar,

Menurut Djamarah (2006:3) bahwa model mempunyai andil yang cukup besar dalam kegiatan belajar mengajar. Model pembelajaran yang diterapkan guru sangat mempengaruhi hasil belajar siswa, dengan model pembelajaran yang sesuai dengan karakteristik materi dan siswa yang akan diajarkan akan menghasilkan proses pembelajaran yang berkualitas yang pada akhirnya akan meningkatkan hasil belajar siswa.

Meskipun demikian model pembelajaran kooperatif tipe Think Pair Share dapat diterapkan pada siswa untuk meningkatkan hasil belajar siswa.

Jadi dapat disimpulkan model pembelajaran sangat menentukan hasil belajar siswa. Namun model pembelajaran kooperatif tipe Think Pair Share dalam mempengaruhi hasil belajar siswa tidak dipengaruhi oleh kecerdasan intelegensi, begitu juga sebaliknya. Adakalanya model 
pembelajaran yang mempengaruhi hasil belajar dan adakalanya kecerdasan intelegensi yang mempengaruhi hasil belajar siswa. Hal ini dikarenakan kedua faktor (model pembelajaran dan kecerdasan intelegensi) memiliki pengaruh yang sama hal ini didukung oleh Ary (1982:365) tidak terjadinya interaksi antara dua variabel karena kedua variabel memberikan pengaruh yang sama.

\section{PENUTUP}

\section{Kesimpulan}

1. Hasil belajar siswa yang diajarkan dengan model pembelajaran kooperatif tipe Think Pair Share secara signifikan lebih tinggi dari pada hasil belajar siswa yang diajarkan dengan model pembelajaran konvensional. Hal ini berarti model pembelajaran kooperatif tipe Think Pair Share dapat dipakai dalam meningkatkan hasil belajar siswa.

2. Terdapat interaksi antara model pembelajaran kooperatif tipe Think Pair Share terhadap hasil belajar siswa atau Ho diterima. Hal ini dikarenakan antara faktor yang mempengaruhi hasil belajar memiliki posisi tersendiri dalam mempengaruhi hasil belajar. Sumbangan yang diberikan suatu model pembelajaran terjadi secara terpisah dan tidak mempengaruhi hasil belajar secara bersama-sama. Adakalanya model pembelajaran yang mempengaruhi hasil belajar dan adakalanya kecerdasan intelegensi yang mempengaruhi hasil belajar.

\section{Saran}

Berdasarkan hasil penelitian yang temukan di kelas eksperimen dan kelas kontrol, maka untuk meningkatkan hasil belajar siswa pada mata pelajaran Kewirausahaan disarankan kepada :.

a. Guru yang mengampu mata pelajaran kewirausahaan:

1) Diharapkan untuk guru yang mengajar di kelas X SMKN Sungai Penuh untuk melaksanakan model pembelajaran yang menarik yang dapat meningkatkan keaktifan siswa dikelas seperti model pembelajaran kooperatif tipe hink Pair Share sehingga dapat meningkatkan hasil belajar siswa. 
2) Menggunakan model pembelajaran yang sesuai dengan karakteristik materi dan siswa yang akan diajarkan serta memperhatikan tingkat kemampuan yang diharapkan dari suatu materi yang akan diajarkan sehingga dapat meningkatkan hasil belajar siswa

b. Kepada siswa agar:

1) Meningkatkan semangat belajar terutama pada kesenangan dalam mencari dan menyelesaikan masalah dalam belajar dan bagaimana agar dapat mempertahankan pendapat ketika berdiskusi dalam kegiatan pembelajaran.

2) Disarankan untuk berlatih aktif dalam berdiskusi kelompok dan menyampaikan pendapat secara intensif.

c. Bagi peneliti lain yang ingin meneliti tentang penggunaan model pembelajaran Think Pair Share harus memperhatikan waktu yang tersedia, materi yang diajarkan, sarana dan prasarana pendukung dan jumlah siswa dalam kelas sehingga penggunaan model pembelajaran Think Pair Share dapat menciptakan pembelajaran yang efektif dan efisien.

\section{DAFTAR PUSTAKA}

Azwar, S. 2004. Pengantar psikologi intelegensi. Yogyakarta: Pustaka Pelajar

Bahtiar. 2009. "Hubungan Antara Kecerdasan Emosional Dengan Prestasi Belajar Siswa Kelas II SMA Negeri 2 Mataram", Jurnal Pemikiran Alternatif Pendidikan, Volume 14 No 2 Tahun 2009.

Dimyati \& Mudjiono. 2006. Belajar dan Pembelajaran, Jakarta: Rineka Cipta.

Febrian Widya Kusuma, Aisyah, dan mimin Nur. 2012. "Implementasi Model Pembelajaran Kooperatif Tipe Think Pair Share Untuk Meningkatkan Aktivitas Belajar Akuntansi Siswa Kelas XI IPS 1 SMA Wonosari”, Jurnal Pendidikan Akuntansi Indonesia Volume X No 2 Tahun 2012. Irianto, Agus. 2009. Statistik Konsep Dasar dan Aplikasinya. Jakarta: Kencana. 
Lie, Anita . 2002. Cooperative Learning. Jakarta: PT Gramedia

Sudjana, Nana. 2009. Penilaian Hasil Proses Belajar Mengajar. Bandung: Remaja Rosdakarya.

Sudjana, Nana.. 2008. Dasar-dasar Proses Belajar Mengajar, Bandung: Sinar Baru Algesindo Offset.

Surayya L, dkk. 2014. "Pengaruh Model Pembelajaran Think Pair Share Terhadap Hasil Belajar IPA Ditinjau dari Keterampilan Berpikir Kritis Siswa", Jurnal Program Pasca Universitas Pendidikan Ganesha, Volume 4 Tahun 2014.

Trianto. 2009. Mendesain Model Pembelajaran Inovatif Progresif. Jakarta: Kencana Prenada Media Group 